\title{
The Impact of the Pandemic on the Level of Students Anxiety
}

\author{
Iryna Synhaivska*[0000-0001-6802-0081], Ganna Gulko ${ }^{[0000-0003-3151-5405]}$ \\ “KROK” University, Kyiv, Ukraine \\ *irinas@krok.edu.ua
}

\begin{abstract}
The past 2020 was unusual for the whole world and changed the lives of most people on the planet. Such concepts as pandemic, health, anxiety, disturbance, limitations, distance and lockdown have become the most popular and relevant. Health safety being everyone's basic need was at stake. We began to worry about our health, avoided meeting other people, tried to adapt to a new way of life that was dictated by new realities. Every day we heard from the news about the number of affected patients and the danger of being in public places. It influenced our psychological state, increased uncertainty, anxiety and disturbance. Such phenomena as fear and worry are derived from and based on emotions which protect a person from danger, signaling the need to get out of this state, situation, change the environment. But prolonged anxiety leads to health deterioration and causes a decrease in efficiency and effectiveness. This study will find out how exactly the pandemic and its consequences (information, health state and stress) affect an individual's anxiety and its components, as well as what factors help reduce anxiety.
\end{abstract}

Keywords: pandemic, anxiety, worry, stress, online learning.

\section{INTRODUCTION}

Currently, a significant amount of researches examines various aspects of student learning in higher education institutions. They analyze their level of progress and the ability to predict it using different data mining systems [1]. These researches examine the peculiarities and influence of synchronous and asynchronous distance learning on academic progress, which is extremely relevant today, under the conditions of the pandemic, lockdown and compulsory distance learning with the aim to reduce the spread of the virus [2]. They also study the issues of result-oriented education (The Outcome Based Education (OBE)) on the example of graduate school [3]. In addition, they study the impact of frequent mobile phone use on people's behavior and well-being, which can cause increased anxiety, increased stress, decreased concentration, distraction [4], as well as the capabilities of cloud technologies and their security as one of the important factors of online learning quality and storage of large amounts of data [5].

In this article we have studied the impact of the pandemic and lockdown, peculiarities of online learning on the psychological state of students, especially on the level of their anxiety and stress. Among the most challenging issues which arise in human practice, a special place is occupied by issues related to mental states. In a number of different mental states which are the subject of scientific research, the greatest attention is paid to the state of anxiety. It is important to emphasize that in psychology there is anxiety as an emotional state (situational anxiety) and as a persistent trait, an individual psychological feature, which is manifested in the tendency to frequent and intense experiences of anxiety. This distinction is most clearly shown in the researches of C. Spielberger, Yu. Khanin, R. Kettel, I. Sarazon $[6 ; 7 ; 8]$.

The psychological dictionary offers the following definitions of worry and anxiety: "worry is the experience of emotional discomfort associated with the expectation of trouble, a sense of danger"; "anxiety is an individual psychological feature that manifests itself in a person's tendency to frequent and intense experiences of anxiety, as well as in the low threshold of its occurrence. And it is considered as a personal formation and/or as a trait of temperament due to the weakness of nervous processes" [9].

\section{BACKGROUND}

The state of worry has been studied by psychologists all over the world (V. Davidson, Ch. Spielberger, T. 
Nemchyn, N. Tarabryna, Yu. Khanin, etc.) [7; 8; 10]. Psychologists assess anxiety as a "central problem of modern civilization" (R. May, E. Erickson), as the most important characteristic of our time [6;11]. Anxiety has acquired the meaning of the basic "vital sense of modernity". In our study, we identify worry and anxiety according to W. Poldinger [12]: "the feeling of an uncertain threat, the nature and timing of which are unpredictable, feelings of diffuse fear and anxious anticipation".

Since anxiety is both an internal characteristic of a person and an externally conditioned situation, scientists distinguish between anxiety as a disposition and anxiety as a condition. Spielberger writes about this distinction as follows: "The state of anxiety (A-State - situational, reactive anxiety) is characterized by subjective, consciously perceived feelings of threat and tension, accompanied by or associated with activation or disruption of the autonomic nervous system. Anxiety as a personality trait (A-Trait - personal, dispositional anxiety), obviously, means a motive or acquired behavioral disposition that forces an individual to perceive a wide range of objectively safe circumstances as containing a threat, prompting them to respond with A-States, the intensity of which does not correspond to the magnitude of the objective danger"[10].

The values of A-Disposition and A-State in the same subject must be correlated in some way. Worry and anxiety are complex and multifaceted concepts which combine not only affective but also other components which play an important role in understanding these concepts. O. Biziuk identified the main structural components of anxiety, which reveal the semantic nature of the affective state [13]: emotional discomfort, asthenic and phobic components of anxiety, anxious assessment of prospects and the need for social protection. These components are complex and ambiguous concepts. Psychologically, they are simultaneously the sides of the same phenomenon - anxiety, and autonomous components of the overall structure of anxiety as a trait. That is why the category of the spectrum as the distribution of values of one variable in its versatility, interconnectedness and unity may be the best term to explain them.

\section{METHODS}

To study the level of anxiety of people and the factors that cause or influence it, we selected 200 respondents full-time students aged 17-25, who have been studying in a distance online format during the last year (since the beginning of the pandemic).

To determine the age and demographic characteristics of the respondents we developed a questionnaire with closed questions, each of them had several possible answers. The questionnaire assesses the age of the respondents, their immediate relationship (whether they are in a relationship, as the relationship is one of the significant factors influencing the level of anxiety), adaptation to distance learning, subjective assessments of anxiety, factors-causes of anxiety and ways to overcome it, as well as a subjective assessment of their own health state (the presence of diseases in the last year).

To determine the level of anxiety and its components we used the "Anxiety Integrative Test" method (O. Biziuk, L. Wasserman, B. Iovliev), which examines the level of manifestation of the main anxiety components (emotional discomfort, asthenic and phobic components, perspective anxious assessment, social protection).

To be able to determine the impact of the pandemic and its phenomena on the level of anxiety, we allowed ourselves to modify the second part of the "Anxiety Integrative Test" method by adding a third block (a copy of the second block, in which we only changed the instructions), which examined the level of respondents personal anxiety by assessing their own condition before the pandemic (until March 2020). Thus, we have received three indicators - the level of situational anxiety at the moment, the level of personal anxiety for the past year during the pandemic and the level of personal anxiety before the pandemic (subjective assessment).

\section{RESULTS}

The authors also studied the level of anxiety earlier (in 2013-2016): at that time full-time students and lyceum students of Ukraine aged 16 to 23 were studied [14]. The level of anxiety in 2013-2016 was observed at a medium level, which corresponded to 4-7 points according to the interpretation of the "Anxiety integrative test" method (O. Biziuk, L. Wasserman, B. Iovliev) - situational (at the moment of the study) anxiety -5.3 , and personal -6.8 points.

The study of anxiety and its components in January 2021 included 200 Ukrainians aged 17 to 63 (the most numerous age range is 17-25 years), the sample numbered $89 \%$ of women. Currently, everyone is studying online.

The analysis of respondents' answers to the questionnaire showed the following results: $37 \%$ of respondents said that they really felt anxious, $66 \%$ of people were in a relationship, $72 \%$ of all answered that they had had other stresses during the year than the pandemic; $32 \%$ said they needed extra help from loved ones or a psychologist to deal with anxiety. Over the last year, $36 \%$ of respondents had SARS, $21 \%$ - had Covid$19,34 \%$ did not get sick at all. Respondents also noted that they experienced increased anxiety while watching the news (37\%), being on public transport (17.8\%), being in rooms with a large number of people $(17.3 \%)$, being at work $(7.1 \%)$, communicating with friends on the topic of the pandemic $(3 \%)$. Among the ways to overcome anxiety used by the respondents (according to them) 
watching movies or listening to music $(39.1 \%)$, work / study $(29.1 \%)$, sports $(8.1 \%)$, household chores. $7.1 \%)$, communication with relatives $(6.6 \%)$ and meditation (3\%) were the most helpful.

The results of the study of worry and anxiety using the Anxiety Integrative Test show that the overall level of anxiety of respondents was significantly higher during 2020 (during the pandemic) (6.6 points - an indicator with a tendency to a high level) than before the spread of the virus (5.6 points - medium level) and during the survey (January 2021) (4.9 points - medium level) (Fig. 1). Explanation: the result in the range from 1 to 3 points shows the low level of anxiety, 4-6 points - medium and 7-9 points - high.

While analyzing the levels of situational anxiety components, we can affirm that at the time of the study, respondents' anxiety took the following forms: people felt tired, had sleep disorders, lethargy, exhaustion (asthenic component) and felt fear for the future (perspective anxious assessment). During 2020 (during the pandemic) anxiety was most often expressed as a decrease in emotional background, dissatisfaction with life (emotional discomfort) and chronic fatigue, exhaustion, lethargy (asthenic components). Before the pandemic, the personal anxiety of the respondents was also caused mostly by emotional discomfort and asthenic emotional background (Figure 1).

When comparing the group of respondents on the parameter of personal anxiety during the pandemic, a significant difference (Student's T-test being used) had been found only by the answers to the questionnaire "need for help" $(\mathrm{F}=7.2, \mathrm{p}<0.05)$ and "the presence of other stresses" $(\mathrm{F}=5.4, \mathrm{p}<0.05)$. Therefore, the subjective assessment of the respondents' own condition in the questions of the questionnaire can be regarded as reliable.

After analyzing the average anxiety rates by groups, we came to the following conclusions. Single people are more anxious, both personally and situationally, than those who are in a relationship (in accordance with average indicators). Anxiety related to a disease has some peculiarities. Thus, the greatest anxiety was felt by those who suffered from somatic and chronic diseases, the least - those who were not sick at all. Interestingly, people with various types of SARS felt more anxious than those with Covid-19 (Figure 2).

The respondents who indicated in the questionnaire that they felt the most anxiety at home or during communication do have high rates of situational and personal anxiety, compared to other reasons. Interestingly, low rates of situational anxiety (during the survey) were observed among those students who indicated that they were trying to deal with anxiety through work / study (3.9 points), household chores (3.7 points), and sports (4.1 points). Low levels of personal anxiety are observed among those students who, to avoid anxiety, do housework (5.1 points), sports (6.1 points), communicate (6.2 points) and immerse themselves in work (6.3 points) (Figure 3$)$.

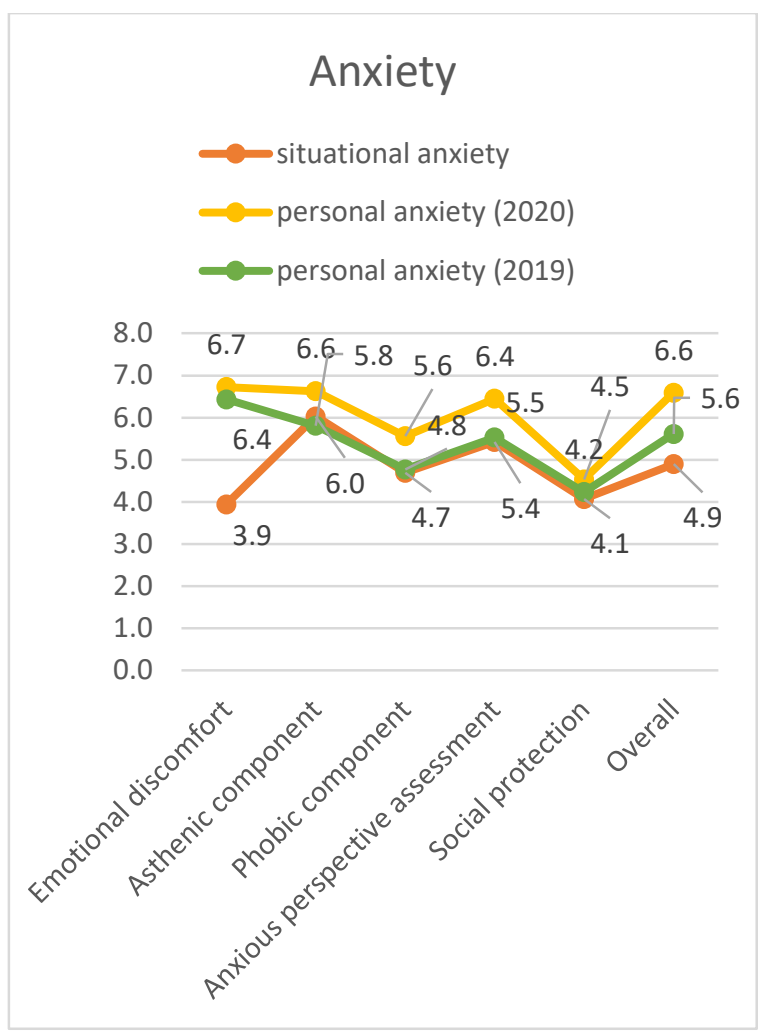

Figure 1. Levels of anxiety and its components by periods

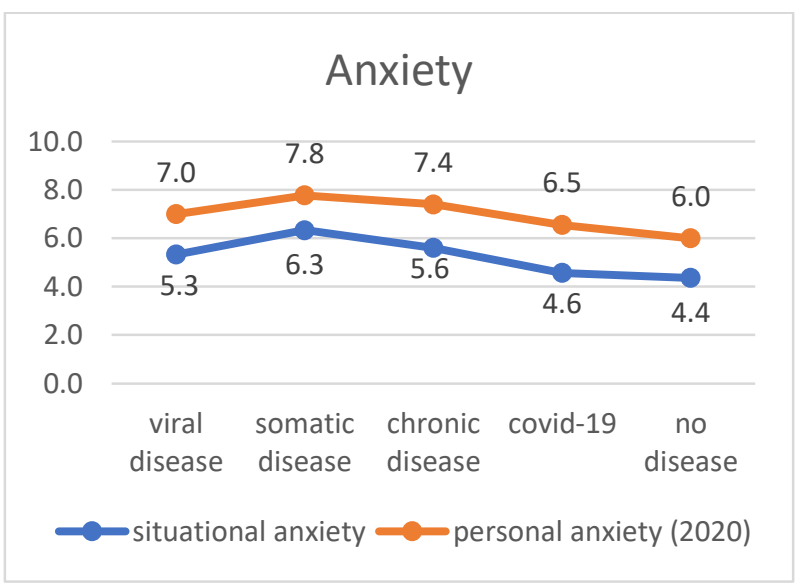

Figure 2. Levels of anxiety by diseases 


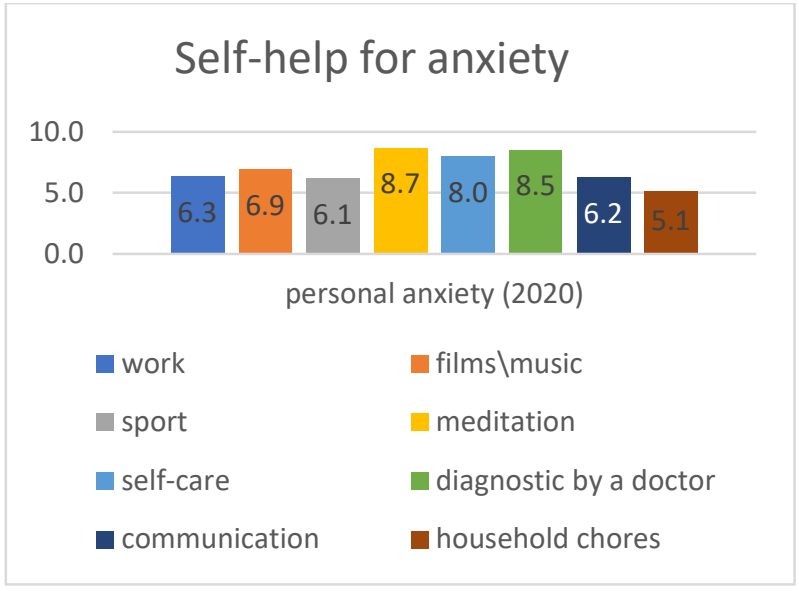

Figure 3 Levels of anxiety by self-help methods

\section{CONCLUSION}

Therefore, we can conclude the following. The pandemic situation has really had a significant impact on the lives of the average Ukrainian students. They have an increased level of anxiety and also feel it personally, a third of people need extra help from loved ones or a psychologist to overcome anxiety.

Distance online learning has its effect on anxiety, and raises questions among students because they were not ready for it. The level of anxiety of respondents increased compared to the year of life before the pandemic (2019). Such factors as watching the news, being in public places with a large number of people or on public transport mostly lead to the anxiety. Homework, immersion in work or study, sports and communication help to fight anxiety. People who went through Covid-19 had lower anxiety rates, the highest anxiety being among those students who had somatic or chronic diseases in the past year.

\section{FUTURE WORK}

Future researches should focus on a broader analysis of anxiety and its factors through the inclusion of other techniques in the study which can identify a variety of anxiety factors. It is also interesting to study the impact of stress on anxiety during a pandemic and to distinguish between the actual factors related to the pandemic and other life stressors which can occur in normal life. Such factors as changes in social activity, forms and frequency of communication, personal meetings, as well as health disorders and their consequences can be regarded as factors caused by the pandemic. It is also important to add a component of the respondent's social status and his or her economic ability to follow anti-epidemiological rules.

\section{REFERENCES}

[1] Rajak, A. Shrivastava, A. Bhardwaj, K. Sh. And Tripathi, A. K. (2019), “Assessment and
Attainment of Program Educational Objectives for Post Graduate Courses", International Journal of Modern Education and Computer Science, vol. 11, no .2, pp. 26-32. DOI: 10.5815/ijmecs.2019.02.04.

[2] Dada, E. G. Abdulkadir, H. Alkali, D. and Oyewola, O. (2019), "An Investigation into the Effectiveness of Asynchronous and Synchronous E-learning Mode on Students' Academic Performance in National Open University (NOUN), Maiduguri Centre", International Journal of Modern Education and Computer Science, vol. 11, no. 5, pp. 54-64. DOI: 10.5815/ijmecs.2019.05.06.

[3] Rajak, A., Shrivastava, A. K. Bhardwaj, S. Tripathi, A. K. (2019), "Assessment and Attainment of Program Educational Objectives for Post Graduate Courses", International Journal of Modern Education and Computer Science, vol. 11, no.2, pp. 26-32. DOI: 10.5815/ijmecs.2019.02.04.

[4] Rahaman, A. Tasnim, S. Hossain, Md S. Majumdar, E. and Hossen, Md R. Islam (Rafiq), (2020), "A Comprehensive Study on Excessive Mobile Phone Use and Preventive Measures", International Journal of Modern Education and Computer Science, vol. 12, no. 3, pp. 33-39. DOI: 10.5815/ijmecs.2020.03.05.

[5] Qayyum, R. Ejaz, H. (2020), "Data Security in Mobile Cloud Computing: A State of the Art Review", International Journal of Modern Education and Computer Science, vol. 12, no. 2, pp. 30-35, DOI: 10.5815/ijmecs.2020.02.04.

[6] Prikhozhan, A.M. (2000), Trevozhnost' u detey $i$ podrostkov: psikhologicheskaya priroda $i$ vozrastnaya dinamika. Voronezh: NPO «MODEK», 2000. 304 p.

[7] Khanin, YU.L. (1976), Kratkoye rukovodstvo $k$ shkale reaktivnoy i lichnostnoy trevozhnosti, $\mathrm{CH}$. D. Spilbergera. Lviv. 18 p.

[8] Sarason, S. B. Davidson, K. S. Lighthall, F.F. and Waite, R.R. (1960), Anxiety in Elementary School Children: A report of research, N.Y.: John Wiley, $654 \mathrm{p}$.

[9] Meshcheryakov B.G. and Meshcheryakov, B. G. (2008), Bol'shoy psikhologicheskiy slovar', SPb. : Praym-Yevroznak, 868 p.

[10] Spielberger, C. D. Gorsuch, R. L. and Lushene R. E. (1970), Manual for the state-trait-anxiety inventory, Palo Alto, California: Consulting Psychologists Press, 10 p. 
[11] Hoyer, J. Van, der Heiden C., Portman M.E. (2011), "Psychotherapy for Generalized Anxiety Disorder”, Psychiatric Annals, № 41 (2), pp. 87-94.

[12] Poldinger, W. (1970), "Aspects of anxiety", Anxiety and tension, pp. 7-21.

[13] Bizyuk, A.P. Vasserman, L.I. and Iovlev, B.V. Primeneniye integrativnogo testa trevozhnosti (ITT), SPb.: SPbNIPNI im. V. M. Bekhtereva, 23 p.

[14] Gulko, G.O. (2016), "Psykholohichni Chynnyk aktualizatsiyi osobistisnikh vlastivostey tryvozhno spektru v sytuatsyy Dosyahnennya", Suchasni pedahohika ta psykholohiya: perspektivni ta prioritetni napryamy naukovykh doslidzhen': materialy mizhnarodnoyi naukovo-praktychnoyi konferentsyy. Kyiv: HO «Kyyivs'ka naukova orhanizatsiya pedahohiky ta psykholohiyi», pp. 4246. 